\title{
Synchronization of jealouses in simowal cows using Gnrh and PGF2 $\alpha$ in the Conception, Michoacán
}

\section{Sincronización de celos en vacas simmental utilizando GNRH y PGF2 $\alpha$ en la Concepcion, Michoacán}

\author{
LUCIO, Rodolfo ${ }^{1 * \dagger}{ }^{\dagger}$, SESENTO, Leticia ${ }^{2}$, BEDOLLA, José Luis Carlos ${ }^{1}$ and CRUZ, Ángel Raul ${ }^{1}$ \\ ${ }^{I}$ Facultad de Medicina Veterinaria y Zootecnia de la Universidad Michoacana de San Nicolás de Hidalgo \\ ${ }^{2}$ Colegio Primitivo y Nacional de San Nicolás de Hidalgo
}

ID $1^{\text {st }}$ Author: Rodolfo, Lucio / ORC ID: 0000-0002-0535-3652, Researcher ID Thomson: X-2391-2018

ID $1^{\text {st }}$ Coauthor: Leticia, Sesento / ORC ID: ORC ID: 0000-0002-6456058X, Researcher ID Thomson: S-6997-2018, CVU CONACYT ID: 449302

ID $2^{\text {nd }}$ Coauthor: Jose Luis Carlos, Bedolla / ORC ID: 0000-0002-2485-5615

ID $3^{\text {rd }}$ Coauthor: Angel Raul, Cruz / ORC ID: 0000-0001-9809-1323, Researcher ID Thomson: S-4975-2918

DOI: 10.35429/EJE.2019.11.6.34.37

Received September 18, 2019; Accepted December 20, 2019

\begin{abstract}
The objective of this work is to reduce the time of presentation of jealousy and improve the indices of conception. The synchronization of estrus or estrus is a technique that is used to achieve the greatest number of pregnant females. GnRH stimulates the release of FSH and LH. FSH promotes follicular growth which increases the concentration of estrogens by the growth of the follicles. In this experiment, 6 cows of the Simmental breed were synchronized with a range of 0 to 7 births, natural riding was provided with a stallion of the same breed. The adoption of synchronization protocols has been increasing today due to the high market demand. A $66.6 \%$ favorable response to treatment was obtained. $33.3 \%$ presented estrus at 26 hours and the other $33.3 \%$ presented estrus at 30 hours after day 10 . Understanding the reproductive physiology of the female and the male allows us to develop synchronization protocols, GnRH and PGF2 $\alpha$, are the methods what better results are producing in our races,
\end{abstract}

Protocol, Synchronization, Zeal

\begin{abstract}
Resumen
El objetivo de este trabajo es reducir el tiempo de presentación de celos y mejorar los índices de concepción. La sincronización de celos o estros es una técnica que se emplea para lograr el mayor número de hembras gestantes. La GnRH, estimula la liberación de FSH y LH. La FSH promueve el crecimiento folicular lo que aumenta la concentración de estrógenos por el crecimiento de los folículos. En este experimento, se sincronizaron 6 vacas de la raza Simmental con un intervalo de 0 a 7 partos, se proporcionó monta natural con un semental de la misma raza. La adopción de protocolos de sincronización ha ido aumentando hoy en día debido a la gran demanda del mercado. Se obtuvo un $66.6 \%$ de repuesta favorable al tratamiento. El $33.3 \%$ presentó estro a las 26 horas y el otro $33.3 \%$ presento celo a las 30 horas después del día 10. Comprender la fisiología reproductiva de la hembra y el macho nos permite desarrollar protocolos de sincronización, la GnRH y PGF2 $\alpha$, son los métodos que mejores resultados están produciendo en nuestras razas,
\end{abstract}

Protocolo, Sincronización, Celo

Citation: LUCIO, Rodolfo, SESENTO, Leticia, BEDOLLA, José Luis Carlos and CRUZ, Ángel Raul. Synchronization of jealouses in simowal cows using Gnrh and PGF2 $\alpha$ in the Conception, Michoacán. ECORFAN Journal-Ecuador. 2019. 6-11: 34-37

\footnotetext{
* Correspondence of the Author (dr.rlucio@ @otmail.com)

$\uparrow$ Researcher contributing as first author.
} 


\section{Introduction}

The synchronization of estrus involves the control or manipulation of the estrous cycle so that the females chosen in a herd express estrus (heat) at approximately the same time. It is a technique widely used in artificial insemination programs, embryo transplantation, birth concentrations and natural mounts. The determining factor in the success of the synchronization is the choice of the appropriate method, which adjusts to the conditions of each animal (Córdoba, 2011).

Synchronization consists in the application of a hormonal product. GnRH or also called gonadotropin-releasing hormone, stimulates the release of FSH and LH. FSH promotes follicular growth which increases estrogen concentration by follicle growth. Subsequently, increasing the level of estrogen stimulates the release of LH which occurs in the form of a peak. LH influences ovulation, when ovulation begins, also does the follicle leutinization process. (Becaluba, 2016).

PGF2 $\alpha$ is a hormone that is naturally produced by the endometrium and acts in the last period of the cycle causing the corpus luteum to regress and resume the next cycle (Colazo, 2007).

The advantages of estrous synchronization (ES) are multiple: it facilitates the implementation of artificial insemination (AI), increases the rate of birth and weaning, reduces the interval between births, programming of females so that they give birth at certain times, geneticall improvement of the herd (Vallejo, 2015).

The signs of heat and their detection play an important role since the percentage of cows in estrus is determined from this. The behavior of the cow in heat generally lasts for 25 hours; This average varies between cows. Physical and behavioral changes are observed; the vulva becomes edematized by the increase of blood to the reproductive organs, discharge of mucus from the vulva, nervousness and excitement, muted, the cows will ride to other cows although a cow in real heat is allowed to ride by another, fold the chin and they lick the flanks of another cow, some walk two or three times more than normal, are grouped into sexually active animals.
The ovule is released approximately 6 to 12 hours after heat. The ovule is detached from the follicle and can be penetrated by the sperm; by this time, it must be ensured that the semen is already inside the cow (Guaqueta, 2009)

There are two basic observation methods for detecting heat; One is the visual observation where two or more periods of the day are selected to observe and detect the cows in heat, the other method consists of constant observation using video cameras that show the day and night activity. Observation is very important, and it needs enough and exclusively time to observe all animals, $70 \%$ of heat will take place between 7:00 pm at 7:00 am. (Marcantonio, 1998).

Feeding also plays an important role in the reproductive cycle, for example any imbalance in the Na: $K$ ratio will affect the estrous cycle, directly and indirectly, through the alteration in protein synthesis and the loss of water regulation, an important factor for the secretions that must accompany the manifestation of heat. On the other hand, the consumption of crude protein or energy deficiency increases urea in the blood and produces tissue toxicity, affecting the endometrium and decreasing the production of prostaglandins, responsible for lysing the corpus luteum, which, if not lysed, causes a long estrous cycle, it can be explained at the hypothalamus-pituitary axis level, in which, low glucose levels inhibit the secretion of GnRH and cause a decrease in LH pulsatility (Campos, 2009).

Finally, an additional factor that induces alteration of estrous cyclicity is phytoestrogens, plants with high lsoflavone contents that have an estrogenic action in the animal organism.

Phytoestrogens are widespread, in clover, alfalfa, corn and intensively grown grasses, they are different from estrogens produced by the animal, but their action is identical on the receptors of the reproductive tract; its metabolization and excretion is different (for example demetilization) and its renal excretion through glucoronosides, likewise the formation of sulfate esters in liver tissue is lower, accumulating in circulation and altering the estrogen of the cycle, this leads to nymphomania of the cows and with it the loss of reproductive function. 


\section{Materials and methods}

The work was carried out, in the town of La Concepción located in the municipality of Morelia in the state of Michoacán de Ocampo and is located at the coordinates: Longitude (dec): - 101.309722, Latitude (dec): 19.7033611. It is located at a height of 2140 meters above sea level. It was held in June of this year.

We worked with a total of 6 cows of the Simmental breed with a range of 0 to 7 deliveries in order to present estrous cycle on day 10 . On the other hand, the natural riding was carried out with a bull of the same breed.

The protocol (Ovsynch) with which this experiment was carried out was based on the luteolytic effect of prostaglandins (PGF2 $\alpha$ ), on the effect of progestogens to inhibit estrus behavior, as well as follicular control and luteum with releasing hormone of gonadotropins $(\mathrm{GnRH})$ in combination with (PGF2 $\alpha$ ).

The first application of GnRH was given to induce ovulation and promote the formation of a new corpus luteum (CL) and a new follicular wave; that is, to return the cow "at the beginning of the estrous cycle". The prostaglandin used on day 7 was to return the new $\mathrm{CL}$ and the last GnRH was administered on day 9 in order to induce ovulation of the new follicle. The reasoning of this protocol is to give one more day for follicular growth that may allow further maturation of the oocyte and ovulation of a larger follicle (López, 2007).

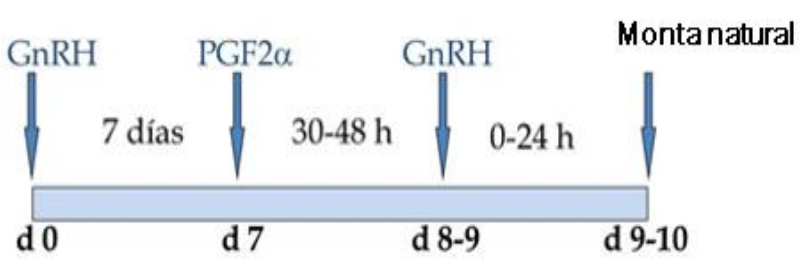

Figure 1

The applications of the injections, in the case of $\mathrm{GnRH}$, were administered ( $2 \mathrm{ml}$ per day 0 and $5 \mathrm{ml}$ per day 9) subcutaneously in the neck table with con inch needle; which consists of the introduction of medications into the subcutaneous tissue; it is applied when it is desired that the medicine be absorbed slowly which allows to ensure a sustained effect.
PGF2 $\alpha$ was applied (5ml per day 7) intramuscularly in the leg with a $1 \frac{1}{2}$ inch needle; which consists of the administration of medicines in the muscular tissue, used mainly in those cases in which a greater rapidity is required; The rate of absorption depends on factors such as muscle mass at the injection site and blood supply. As mentioned, the detection of jealousy in a herd plays an important role since it allows indirectly to increase monetary gains due to a good observation of estrus and therefore pregnant cows which in the future the calf will represent monetary income to a production unit Therefore, for the detection we use the method of visual observation which consisted of 3 times for 12 hours a day 10 .

\section{Results and discussion}

The synchronization was carried out in 6 cows of which $66.6 \%$ of the favorable response to the treatment was obtained. $33.3 \%$ had estrus at 26 hours and the other $33.3 \%$ had heat at 30 hours after day 10 . The results obtained are similar to those found by (López, 2007) who used the Ovsynch protocol, obtaining a $68.75 \%$ heat manifestation at the time of the second application of GnRH.

Among the alternatives to contribute to an improvement in the reproductive efficiency of cattle, the use of jealousy synchronization protocols is considered since the investigations carried out show that the hormonal manipulation of the ovarian cycle of cattle with good results is feasible, in addition, it allows to have better control in the herd for an artificial insemination program.

\section{Conclusions}

The process of synchronization of the females so that they enter in heat at a certain moment allows the Artificial Insemination in Fixed Time (IATF) favoring the use of the Artificial Insemination (AI) on a large scale or the natural mount, and diminishes the labor force necessary to monitor females in heat. The adoption of synchronization protocols has been increasing today due to high market demand. 
The greater understanding of the function of the reproductive system of the female and the male has allowed us to understand how the synchronization protocol already performed develops and how it acts in the herd, as well as the understanding of bovine reproductive physiology allows us to choose the protocol of most appropriate synchronization for each herd. It is worth mentioning that good management, nutrition and attention to detail are extremely important for success..

\section{Refernces}

Becaluba F., 2006, Métodos de sincronización de celos en bovinos. Sitio argentino de Producción Animal. P.p. 1-3.

Campos R., Hernández E. A., RELACIÓN NUTRICIÓN FERTILIDAD EN BOVINOS: Un enfoque bioquímico y fisiológico. Universidad Nacional de Colombia. Colombia. P.p. 1-57.

Colazo M. G., Mapletoft R. J., Et al., 2007, El uso de tratamientos hormonales para sincronizar el celo y la ovulación en vaquillones. Ciencia Veterinaria. 9:(1). La Pampa, Republica de Argentina. P.p. 1-16.

Córdova A. B., 2011, Protocolos de Sincronización y superoculación para transferencia de embriones bovinos. Universidad de Cuenca: Facultad de Ciencias Veterinarias. Cuenca, Ecuador.

DeJarnette M., Protocolos de sincronización para vacas lecheras. Reproductive Solutions. Dr. Ray Nebel: Especialista en reproducción.

García A. F., Rabaglino M. B., y Torreta M. E., Re--sincronización de celos utilizando progestágenos y benzoato de estradiol, en vacas de carne (Bos Taurus) con cría al pie, manejadas en sistemas pastoriles de regiones áridas. REDVET. 18:(10). Málaga, Venezuela. P.P. 1-12.

Guaqueta H., 2009, CICLO ESTRAL: Fisiología básica y estrategias para mejorar la detección de celo. Revista de la facultad de medicina veterinaria y zootecnia. 59:(2). Bogotà, Colombia. P.p. 163-183.
Lenis Y. Y., Gutiérrez M. T., Tarazona A. M., 2010, Efecto de los fitoestrógenos en la reproducción animal. Revista facultad nacional de Agronomía. 63:(3).

López H., (2007), Consideraciones fundamentales para la implementación de programas de inseminación artificial a tiempo fijo. ABS Global México.

Marcantonio S., 1998, ¿Comó detertar celo?. Sitio argentino de Producción Animal. P.p. 1823.

Palomares N. R., De Ondiz S. A., Et al., 2005, Efecto de dos protocolos hormonales a base de progesterona sobre la tasa de ovulación y ocurrencia de celos anovulatorios en vacas mestizas tropicales. Revista Científica. 15:(3). Maracaibo, Venezuela. P.p. 242-251.

Sepulveda J., Protocolos de sincronización para inseminación a tiempo fijo. Repromax.

Thorson S., Eeligiendo un protocolo de sincronización para su hato. Corporative Resources International.

Vallejo D. A., Muñoz Y. A., Etal., 2015, Sincronización de la ovulación en bovinos utilizando gonadotropina coriónica esquina con amamantamiento restringido y sin este. Revista Médica Veterinaria. 35. Bogotá, Colombia. P.p. 83-91.

Fernández F. J. A., Arieta R. R. J., Et al., 2017 https://www.engormix.com/ganaderiacarne/articulos/metodos-sincronizacion-celosbovinos-t27252.htm 